\title{
The Relationships of Perceived Organizational Support (POS) With Positive Work Behavior: Mediating Role of Job Satisfaction, Affective Commitment, and Felt Obligation
}

\author{
${ }^{1}$ Hafid Aditya Pradesa, ${ }^{2}$ Margono Setiawan, ${ }^{3}$ Djumahir, ${ }^{4}$ Mintarti Rahayu \\ The doctoral program Graduate Student Faculty of Economics and Business Brawijaya University \\ Faculty of Economics and Business Brawijaya University
}

\begin{abstract}
The purpose of this study is to examine the mediating effect of job satisfaction, affective commitment, and felt obligation in relationship of perceived organizational support toward work positive behavior among postal employees. There are 128 from 163 postal employees was surveyed, and the response rate is about 78,52 \%. Data was analyzed by using Partial Least Square, which the result shown that from 5 hypothesis proposed, 1 hypothesis was rejected. The main findings are that there are mediating role of job satisfaction, affective commitment, and felt obligation between POS and work positive behavior. Result show that here that affective commitment not founded as the most important among the mediating variables. Job satisfaction has founded as strongest impact on the mediating relationship among them. Implications for future research are discussed.
\end{abstract}

Keywords: Perceived Organizational Support, Job Satisfaction, Affective Commitment, Felt Obligations, Positive Work Behavior.

\section{Introduction}

PT. Pos Indonesia is a State-Owned Enterprises (SOEs) that are engaged in services, in particular services of mail, logistics and finance. In achieving performance and profit targets that have been determined, based on the role and performance in operational units in all regional offices in Indonesia, so the vision to become a leader in mail services, logistic \& finance can be achieved. PT Pos Indonesia today faces many internal problems such as low productivity and performance of employees as well as other assets.

The main challenge of PT Pos Indonesia, which is implicit in the results include:

(1) The quality of service is low;

(2) Marketing and branding are weak;

(3) Reputation Weak;

In the scope of PT Pos Indonesia Malang employee performance issues to be one of the important things to be observed due to poor organizational performance can be caused by one of them as individuals (employees) in the organization can not demonstrate high performance or at least as expected.

Framework in terms of organizational psychology and social exchange theory, explains the relationship between perceptions of organizational support on work behavior in the majority of previous studies have highlighted the supportive relationships that picture of them. More than 80 studies that tested successfully compiled on a meta-analysis of perceptions of organizational support, the following antecedents and outcomes the results (including the impacts on individual performance), which has been conducted since 1986 to 2000 (Rhoades and Eisenberger, 2002).

Blau in Poloma (2010) himself admits that not all social exchange relationships are symmetrical and balanced based on the exchange pattern. Due to the imbalance of the exchange relationship (no side higher and lower) then it will give their consequences - each.

Based on the empirical results of one of the most important factors in mediating the relationship is affective commitment (the result / outcome of the main perceptions of organizational support by Rhoades and Eisenberger, 2002). View of social exchanges mentioned that employee commitment to the organization is strongly influenced by their perceptions of the commitment of the organization to the employees. So that affective commitment is seen as the main thing that is able to mediate the relationship between perceptions of organizational support with performance (Eisenberger et al., 2001; Wayne et al., 1997; Lew, 2009; Rhoades et al., 2001; Rhoades and Eisenberger, 2002).

From the findings of this study will be able to see how the process of social exchange that exist within organizations can positively influence employee behavior through the mediation work of the mechanism of employee attitudes towards the organization and the work that is affective commitment, job satisfaction, and perceptions of perceived employee obligations in PT Pos Indonesia Malang . 
In search of solution about business revitalization, many scholars was thought about financial and organizational performance. As many scholars known, there are too many kind of matters that could affect job performance. The changing nature of business environment, job itself and organizational climate has challenged traditional views of individual work performance, yet there are evolution about how we look and rate the performance. Griffin, Neal and Parker (2007) shown that from 1993 till 2006, performance frameworks and taxonomies have been developed rapidly. The evolution of performance domain is about defining different dimensions and linking them to the context in which work is performed.

To explain work performance from the social exchange perspective, in most of previous studies have highlighted framework with a supportive relationship between them. Social exchange theory emphasizes the concepts of obligation and reciprocal (Poloma, 2008, Eisenberger et al, 1986). Employees who feel supported by organization can be expected to perform better than those who experience low levels of support (Eisenberger, Fasolo, LaMastro, 1990; Eisenberger et al., 2001; Shore and Wayne, 1993). Reciprocation of these organizational treatment can be shown by the work performance of an employee (Rhoades and Eisenberger, 2002).

Compared to other such as job satisfaction, organizational commitment is a dominant form of attitude as a result of organizational support (Allen et al, 2003; Laschinger et al., 2006). Affective commitment, which is more specific, has found as main result of perceived organizational support (Wayne et al, 1997; Eisenberger et al., 2001, Lew, 2009).

There are inconsistencies about how organizational support affect employee performance (significant toward extra role performance - Wayne et al, 1997; Rhoades and Eisenberger, 2002; while positive and reliable toward in-role performance and not significant with extra role performance - Lycnh, Eisenberger, Armeli, 1999). This empirically shows that how perceived organizational support related to performance differently. Perceived organizational support are directly related toward job performance, but Rhoades and Eisenberger (2002) said that the direct relationship is weaker. Pazy and Ganzach (2009) asserted that perceived organizational support can not directly effect employee performance. Liu (2004) revealed felt obligations has mediating the relationship between perceived organizational support on organizational citizenship behavior, inrole performance, and organizational commitment.

According to the previous empirical results, affective commitment were found as the most important variable that mediate perceived organizational support toward behavioral outcome. Therefore, the most important factor mediating the relationship is affective commitment (Rhoades and Eisenberger, 2002). Despite of that, affective commitment is not always be founded as a critical antecedent of performance despite having no previous studies assessing the relationship (Shore and Martin, 1989, Nijhof et al., 1998, Suliman and Iles, 2000, Suliman, 2002).

Previous research also demonstrated the mediating variabels among the relationship between perceived organizational support and behavioral outcome. This article therefore attempts to bridge these gap in the literature by arguing what these constructs are important and evaluate which are the most important mediating variable among them.

What is the relationship between perceived organizational support, job satisfaction, affective commitment, and felt obligation toward positive work behavior?

\section{Perceived Organizational Support}

\section{Literature Review}

Many scholars describes the theoretical foundations for the social exchange model of relation between employee - organization. Organizational support theory (Eisenberger, Huntington, Hutchison, and Sowa, 1986; Shore and Shore, 1995) supposes that to determine the organization's readiness to reward increased work effort and to meet socioemotional needs, employees develop global beliefs about the extent to which their employing organization both values their contributions and cares about their well-being. Employees see their employment as a reciprocal exchange that extends beyond a formal contract.

By norm of reciprocity, employees will reciprocate organization with a high level of support for them, by increasing their efforts to help organizations achieve goals (Aselage and Eisenberger, 2003). On the basis of the norm of reciprocity, POS would strengthen affective commitment to the organization and increase efforts made on its behalf (Eisenberger et al., 1986; Shore \& Shore, 1995). This mean that perceived organizational support could be the commitment from organization to their employee. Social exchange theorists have argued that the receipt of resources from another person is valued more highly if thought to be discretionary rather than dictated by circumstances (Eisenberger et al., 1997).

\section{Job Satisfaction}

Job satisfaction has been defined as an pleasant / unpleasant emotional feelings that are the result of the assessment of a person's job or job experience, it presented what someone feel and think about the job (Locke, 
1976, Judge and Klinger, 2007, 2009; Colquitt et al, 2009). Depart from the definition of Locke, Hulin and Judge (2003) argued that job satisfaction include multidimensional psychological response on a person's job. Psychological response has a cognitive component (or evaluative), affective (or emotional), and behavioral (or behavior). Tripartite conceptualization of job satisfaction is very in keeping with the conceptualization of the social attitudes on a satisfaction (Jex, 2002).

Empirically, previous research about POS and job satisfaction has tested the direct effect between them. POS has been hypothesized to influence employees' general affective reactions to their job, including job satisfaction (Rhoades \& Eisenberger, 2002). We expect POS will be positively related to job satisfaction, and job satisfaction will be positively related to work positive behavior, and as the mediating variabel between them.

\section{Affective commitment}

Commitment is a broad-ranging concept that crosses many organizational and sociological domain, and is one of the attitude model of the employees in the organization which are discussed and studied by many scholars. According to Greenberg and Baron (2008), employees with high organizational commitment of employees is more stable and more productive and ultimately more profitable for the organization as well. Robbins (2007) revealed that the commitment is the identification of a particular organization and its purpose, and a willingness to maintain membership in the organization. While Jex (2002) expressed the opinion that organizational commitment is considered as the degree to which employees are dedicated to the organization where they work, a willingness to provide work effort and even surpass them, as well as the likelihood that they will keep the membership as part of the organization. Commitment shows both feelings and behavioral tendencies employee against his organization.

Typology of organizational commitment is also in accordance with that proposed by Allen and Meyer (1990) with three components: affective commitment, normative commitment, and continuance commitment.

\section{Felt Obligations}

The concept of obligation, basically have differences and some similarities with the concept of duty. The concept of "duty" is more binding to the feelings or conscience and personal moral standards as reflected when we say about the "perceived obligations" (Brandt, 1964). Individual differences make employees react differently to the perceived obligation to the following organizations also contribute to the fulfillment of their obligations differently in relation to the organization's employees (Guest, 2004). Robinson, Kraatz, and Rousseau (1994) defines the duty to be a belief, held by the employee or the employer, the individual - each of them based on a promise or liabilities for acts in relation to others. At the end of the obligation is one of the basic components of social exchange relationships.

Aselage and Eisenberger (2003) reinforces this view by asking one of the proposition that felt obligation as mediating variables of perceived organizational support and withdrawal behavior, the in -role and extra performance. Liu (2004) found that employee perceptions of perceived obligations as an important mediator in the relationship between perceived organizational support to work, attitudes and behavior of employees.

\section{Positive Work Behavior}

Many scholars and previous research assess the performance as one of the work behavior (Jex, 2002; Tett, Fox, Palmer, 2003; Griffin, Neal, Parker, 2007) which would be productive for the organization if the behavior is appropriate and consistent with achieving the goals and values. Because the concept of performance dynamically evolving, it simplify that performance / work performance is not the same as measuring performance / measurement of performance (Jex, 2002).

Based on the construction of performance that has been developed before, and in the context of change, uncertainty, and also role of the job, Griffin et al (2007) developed a new model of appropriate role in job performance. The model highlights the issue in the clarification of the role of the three levels of appropriate behavior may contribute to the effectiveness (individual, team, and organization), and the three forms of the behavior of performance itself (skills, adaptability, and proactive behavior).

\section{Model Development And Hypothesis}

This study aims to examine the relationship between perceptions of organizational support to the positive work behaviors mediated by job satisfaction, affective commitment, and felt obligation.

The model shown in figure 1 includes outcomes of perceived organizational support. Job satisfaction, affective commitment, felt obligation was tested as mediating variables in the relationship between perceived organizational support and positive work behavior. 
1. The relationship between perceptions of organizational support to employee performance

a) According to the study - previous research such as: Rhoades and Eisenberger (2002); Lynch, Eisenberger, Armeli (1999); Armeli, Eisenberger, Fasolo, Lynch (1998) note that perceptions of organizational support may affect performance.

b) According to the study - previous research such as: Wayne, Shore, and Liden (1997), and Ganzach Pazy (2009) note that perceived organizational support had no direct effect on performance.

2. The relationship between perceptions of organizational support to job satisfaction

a) previous research that reported such as Randall, Cropanzano, Bormann, Birjulin (1999), Allen et al (2003), Pack (2005), Jawahar and Hemmasi (2006) stated that the perception of organizational support have a strong relationship with job satisfaction .

b) Eisenberger, Cummings, Armeli, Lynch (1997) and Shore and Tetrick (1991) stated that perceived organizational support and job satisfaction is a construct may be similar but are different from each other, and both are interrelated.

c) Meta-analysis Rhoades and Eisenberger (2002) mentioned among others that job satisfaction as one of the main results of the perception of organizational support.

\section{The relationship between perceptions of organizational support with affective commitment}

a) Lew (2009), Pack (2005), Rhoades and Eisenberger (2002) generally found that the main outcome of perceived organizational support is affective commitment.

b) Shore and Wayne (1993) and Hunter (2011) adds that the perception of organizational support may explain a significant proportion of the differences in the behavior of organizational membership through affective commitment. Research and theory also emphasize that POS is strongly related to organizational commitment, and yet thease are distinct construct among them ( Eisenberger et al., 1997; Shore \& Tetrick, 1991).

4. The relationship between perceptions of organizational support perceived obligation

a) Lew (2009) states that the perceived obligation is the result of the perception of organizational support.

b) Eisenberger, Armeli, Rexwinkel, Lynch, Rhoades (2001) and Arshadi (2011) states that the perceived obligation to mediate the relationship between perceptions of performance in accordance with organizational support roles.

We propose that there are three variabels that could mediates relationship between perceived organizational support and positive work behavior. Findings about the mediating role in the POS - work positive behavior relationship have been mixed, which has been discussed that affective commitment as the most important among them. As for this study the hypothesis proposed are as follows:

H.1.Job satisfaction will mediate the relationship between perceived organizational support and positive work behavior

H.2.Affective commitment will mediate the relationship between perceived organizational support and positive work behavior

H.3. Felt oblitgation will mediate the relationship between perceived organizational support and positive work behavior

H.4.Increased job satisfaction will increase the level of employee affective commitment

P.5.Increased felt obligation among employees will increase the level of employee's affective commitment

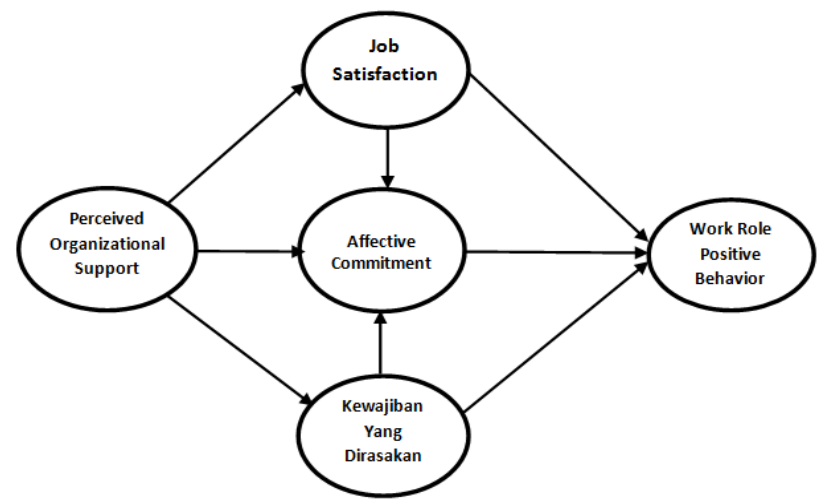

Sumber : 


\section{Participants and procedures}

\section{Methodology}

Data collected from postal employees of PT Pos Indonesia Malang who is a permanent and have a grade 10 to 17 . There are 163 employees whom grade is about 10 to 17 , and 128 employees from 163 employees were participate in this strudy. The response rate amount to $78.52 \%$.

\section{Measure}

An 8-item shortened version of the Survey of Perceived Organizational Support (Eisenberger et al., 1990) was used to measure POS. Response options ranged from (1) 'strongly disagree' to (5)'strongly agree'. Sample item include "My organization really cares about my well-being”. Cronbach alpha was found 0.939.

A 15-tem scale developed by Hulin and Judge (2003) and Colquitt et al (2009) was used to measure job satisfaction. Response options ranged from (1) 'strongly disagree' to (5)'strongly agree'. Sample item include "My organization give pay better than competitor". Cronbach alpha value was found to be 0.884 .

A 6-item scale by Allen and Meyer (1990) was used to measure affective component of organizational commitment. Response options ranged from (1) 'strongly disagree' to (5)'strongly agree'. Sample item include "My organization give pay better than competitor". Cronbach alpha value was found to be 0.902 .

A 6-item scale by Eisenberger, Armeli, Rexwinkel, Lynch, Rhoades (2001) was used to measure employees' felt obligation to care about the organization and to help reach it goals. Response options ranged from (1) 'strongly disagree' to (5)'strongly agree'. Sample item include "My organization give pay better than competitor". Cronbach alpha value was found to be 0.802 .

Positive work behavior is a positive behavior in work activities that contribute to the effectiveness of the work is measured by 15 items of the statement as an adaptation of Griffin, Neal, and Parker (2007). Cronbach alpha value was found to be 0.896 .

\section{Data Analysis}

In this research, technical analysis is the variance-based SEM or Component-based SEM, which is called the Partial Least Square (PLS). PLS is a factor indeterminacy powerful analytical method, because it does not assume the data have a certain scale of measurement, the number of small-scale, and can also be used to confirm the theory (Ghozali, 2008; Hair et al.2010).

\section{Hasil Dan Pembahasan}

Statistic reported :

\begin{tabular}{|l|r|r|c|}
\hline \multicolumn{1}{|c|}{ Relationships } & $\begin{array}{c}\text { Original } \\
\text { Sample } \\
\text { Estimate }\end{array}$ & t-statistic & P Value \\
\hline POS -> Job Satisfaction & 0,919 & 49,643765 & 0,000 \\
\hline POS -> Affective Commitment & 0,563 & 3,915672 & 0,000 \\
\hline POS -> Felt Obligation & 0,883 & 49,444163 & 0,000 \\
\hline Job Satisfaction -> Affective Commitment & 0,249 & 2,137916 & 0,017 \\
\hline Job Satisfaction -> Positive Work Behavior & 0,362 & 2,663842 & 0,004 \\
\hline Felt Obligation -> Affective Commitment & 0,159 & 1,673437 & 0,051 \\
\hline Felt Obligation -> Positive Work Behavior & 0,245 & 2,469168 & 0,007 \\
\hline Affective Commitment -> Positive Work Behavior & 0,332 & 2,372130 & 0,010 \\
\hline
\end{tabular}

Dengan model struktural ini, diuji delapan hubungan antar variabel. Hasil pengujian hubungan antar variabel penelitian secara lengkap disajikan berikut ini :

\section{Pengaruh Persepsi Dukungan Organisasi Terhadap Perilaku Kerja Positif Melalui Kepuasan Kerja Pegawai}

Berdasarkan hasil penelitian dan diagram tabel hasil untuk pengujian hipotesis maka untuk hipotesis pertama dalam penelitian ini dinyatakan diterima. Karena persepsi dukungan organisasi mempunyai pengaruh terhadap kepuasan kerja, berikut kepuasan kerja juga ditemukan mempunyai pengaruh terhadap perilaku kerja positif karyawan.

Kedua jalur hubungan yang ditemukan signifikan ini memberikan bukti bahwa : (1) terdapat pengaruh tidak langsung persepsi dukungan organisasi terhadap perilaku kerja positif melalui kepuasan kerja pegawai, atau dengan kata lain kepuasan kerja menjadi hal yang dapat memediasi hubungan diantara persepsi dukungan organisasi dan perilaku kerja positif. (2) efek dari persepsi dukungan organisasi terhadap perilaku kerja positif dapat bekerja melalui kepuasan kerja. 
Sehingga dapat dinyatakan dalam berperilaku kerja, seorang pegawai akan menilai perlakuan yang diterima dari organisasi untuk kemudian merasakan hal - hal yang diterima dan melekat dalam pekerjaan apakah sudah sesuai dengan nilai yang diharapkan individu tersebut. Penilaian antara nilai yang dirasakan dan yang diharapkan dalam pekerjaan ini akan mendorong penilaian terhadap perlakuan yang diterima dari organisasi dalam membentuk perilaku positif dari seorang individu dalam bekerja.

\section{Pengaruh Persepsi Dukungan Organisasi Terhadap Perilaku Kerja Positif Melalui Komitmen Afektif Pegawai}

Berdasarkan hasil penelitian dan tabel jalur hasil untuk pengujian hipotesis maka untuk hipotesis kedua dalam penelitian ini dinyatakan diterima. Karena persepsi dukungan organisasi mempunyai pengaruh terhadap komitmen afektif, berikut komitmen afektif sendiri juga ditemukan mempunyai pengaruh terhadap perilaku kerja positif karyawan.

Kedua jalur hubungan yang ditemukan signifikan ini memberikan bukti bahwa efek dari persepsi dukungan organisasi terhadap perilaku kerja positif dapat bekerja melalui komitmen afektif dari pegawai. Dapat disimpulkan juga bahwa komitmen afektif menjadi hal yang dapat memediasi hubungan diantara persepsi dukungan organisasi dan perilaku kerja positif.

Sehingga dapat dinyatakan bahwa seorang pegawai akan menilai perlakuan yang diterima dari organisasi untuk kemudian perasaan keterikatan diri dan emosional terhadap organisasi akan menunjang individu tersebut dalam berperilaku kerja yang positif. Tetapi dari hasil koefisien jalur yang ditemukan berdasarkan hasil analisis, komitmen afektif tidak dalam posisi yang dominan dalam menengahi hubungan diantara persepsi dukungan organisasi terhadap perilaku kerja positif.

\section{Pengaruh Persepsi Dukungan Organisasi Terhadap Perilaku Kerja Positif Melalui Kewajiban Yang Dirasakan Pegawai}

Berdasarkan hasil penelitian dan tabel jalur hasil untuk pengujian hipotesis maka untuk hipotesis ketiga dalam penelitian ini dinyatakan diterima. Karena persepsi dukungan organisasi mempunyai pengaruh terhadap kewajiban yang dirasakan, berikut kewajiban yang dirasakan juga ditemukan mempunyai pengaruh terhadap perilaku kerja positif karyawan.

Kedua jalur hubungan yang ditemukan signifikan ini memberikan bukti bahwa efek dari persepsi dukungan organisasi terhadap perilaku kerja positif dapat bekerja melalui kewajiban yang dirasakan dari pegawai. Kewajiban yang dirasakan menjadi hal yang dapat memediasi hubungan diantara persepsi dukungan organisasi dan perilaku kerja positif.

Seorang pegawai akan menilai perlakuan yang diterima dari organisasi untuk kemudian penilaian positif akan membentuk perasaan berhutang kepada organisasi yang harus dikembalikan akan menunjang individu tersebut dalam berperilaku kerja yang positif. Kewajiban yang dirasakan sebagai wujud balasan sikap atau perlakuan terhadap organisasi atas tingkat persepsi dukungan organisasi yang dirasakan pegawai ternyata dapat dapat memberikan efek pengaruh secara langsung terhadap perilaku kerja positif.

\section{Pengaruh Persepsi Kepuasan Kerja Terhadap Komitmen Afektif Pegawai}

Berdasarkan hasil penelitian dan diagram jalur hasil untuk pengujian hipotesis maka untuk hipotesis keempat dalam penelitian ini dinyatakan diterima.

Kepuasan kerja sebagai hal yang mampu memprediksi perasaan afeksi diri dan keterikatan emosional individu terhadap organisasi, atau dengan kata lain kepuasan kerja mempunyai pengaruh signifikan positif terhadap komitmen afektif. Hal ini sejalan dengan kondisi di lapangan bahwa para pegawai PT Pos Indonesia merasa berkomitmen sebagai hasil dari rasa kepuasan mereka terhadap hal - hal yang melekat pada pekerjaan, terutama tentang kepuasan pegawai terhadap gaji dan kebijakan promosi yang diterapkan dalam perusahaan.

Gaji dan promosi ini merupakan dua hal terpenting bagi rasa puas seorang pegawai PT Pos Indonesia, dimana kepuasan tersebut akan mendorong rasa berkomitmen afektif terhadap organisasi yang banyak direfleksikan dengan rasa kebanggaan bekerja dan kesamaan nilai yang dianut seorang pegawai dengan perusahaan.

\section{Pengaruh Persepsi Kewajiban Yang Dirasakan Terhadap Komitmen Afektif Pegawai}

Berdasarkan hasil penelitian dan diagram jalur hasil untuk pengujian hipotesis maka untuk hipotesis kelima dalam penelitian ini dinyatakan ditolak. Kewajiban yang dirasakan tidak mempunyai hubungan pengaruh yang signifikan terhadap terbentuknya komitmen afektif dari pegawai.

Kewajiban yang dirasakan, yang terdiri dari faktor utama seperti kewajiban melakukan tindakan dalam membantu organisasi dalam mencapai tujuan, dan kewajiban memberi seluruh energi dalam mencapai tujuan pekerjaan tidak menjadi hal yang mampu memprediksi keterikatan diri dan emosional pegawai terhadap organisasinya. Adapun keterikatan diri dari pegawai pos ini lebih dibentuk oleh rasa kebanggaan bekerja dan 
kesamaan nilai yang dianut seorang pegawai dengan perusahaan. Sehingga rasa berkewajiban seorang pegawai pos tidak dapat mendorong terbentuknya rasa keterikatan diri dan emosional terhadap perusahaan.

\section{Results}

With this structural model, the relationship between variables was tested eight. The results of testing the relationship between the study variables are presented in full below:

\section{Influence Perceptions of Organizational Support Work Toward Positive Behavior Through Employee Job Satisfaction}

Based on these results and results table diagrams to test the hypothesis that for the first hypothesis in this study are accepted. Because the perception of organizational support has an influence on job satisfaction, job satisfaction also following were found to have a positive influence on employee work behavior. Both pathways found significant relationships provide evidence that: (1) there is an indirect influence perceptions of organizational support for the positive work behavior through employee satisfaction, or in other words, job satisfaction to be able to mediate the relationship between perceptions of organizational support and positive work behavior . (2) the effects of perceived organizational support to work behaviors can positively work through job satisfaction.

So it can be stated in the act of work, an employee will assess the treatment received from the organization to then feel - it received and attached to the work if it is in accordance with the expected value of the individual. Assessment between perceived value and expected in this work will encourage the assessment of the treatment received from the organization in shaping positive behavior of an individual at work.

2. Influence Perceptions of Organizational Support Work Toward Positive Behavior Through Employee Affective Commitment

Based on the results of the research and a table to track the results of the hypothesis testing for the second hypothesis in this study are accepted. Because the perception of organizational support has an influence on affective commitment, following their own affective commitment was also found to have a positive influence on employee work behavior.

Both lines were found to be significant correlation provides evidence that the effect of the perception of organizational support to work behaviors can positively work through affective commitment of the employees. It can be concluded also that affective commitment to things that can mediate the relationship between perceptions of organizational support and positive work behavior.

So it can be stated that an employee will assess the treatment received from the organization to later feelings of self and emotional attachment to the organization will support the individual in a positive work behavior. But from the path coefficients were found based on the analysis, affective commitment is not in a dominant position to mediate the relationship between perceptions of organizational support for the positive work behaviors. 3. Influence Perceptions of Organizational Support Work Toward Positive Behavior Through Employee Perceived Obligation

Based on the results of the research and a table to track the results of the hypothesis testing for the third hypothesis in this study are accepted. Because the perception of organizational support has an influence on the perceived obligation, following the perceived obligation was also found to have a positive influence on employee work behavior.

Both lines were found to be significant correlation provides evidence that the effect of the perception of organizational support for the positive work behaviors can work through the perceived liability of the employee. Be perceived obligation to mediate the relationship between perceptions of organizational support and positive work behavior.

An employee will assess the treatment received from the organization to a positive assessment will then form a sense of obligation to the organization to be refunded will support the individual in a positive work behavior. Liability perceived as a form of retaliation or victimization attitudes toward the organization's perceived level of perceived organizational support employee was able to give effect to the direct effect on the behavior of the positive work.

4. Influence Perceptions Of Job Satisfaction Employee Affective CommitmentBased on the findings and results of the path diagram for the hypothesis testing for the fourth hypothesis in this study are accepted.

Job satisfaction as being able to predict the feelings of affection and emotional attachment to the individual self to the organization, or in other words, job satisfaction has a significant positive effect on affective commitment. This is in line with the conditions on the ground that the employees of PT Pos Indonesia was committed as a result of a sense of satisfaction at the things - things that are attached to the job, especially on employee satisfaction towards the salary and promotion policies are implemented within the company. 
Salary and promotion are the two most important things for a sense of satisfaction an employee of PT Pos Indonesia, which will encourage a sense of satisfaction affective commitment to the organization with a sense of pride reflected much work and shared values espoused an employee with the company.

5. Perceptions Influence Perceived Obligation Against Employee Affective Commitment Based on the findings and results of the path diagram for the hypothesis testing for the fifth hypothesis in this study be rejected. Liability is not perceived to have a significant effect on relationship formation affective commitment of the employees.

Perceived obligations, which consist of the main factors such as the obligation to act in assisting the organization in achieving its objectives, and the obligation to provide all the energy in achieving the objectives of the job is not being able to predict the self and emotional attachment to the organization's employees. The attachment of the postal workers themselves are more shaped by a sense of pride in work and shared values espoused an employee with the company. So that sense of obligation a postal employee can not encourage the formation of a sense of self and emotional attachment to the company.

\section{Diskusi}

Hasil penelitian ini secara teoritis dapat tergambarkan dari pembuktian hubungan kausalitas antar kostruk atau variabel laten persepsi dukungan organisasi terhadap perilaku kerja positif melalui kepuasan kerja, komitmen afektif, dan kewajiban yang dirasakan pegawai PT Pos Indonesia Malang. Dalam hal ini terdapat beberapa temuan secara khusus, antara lain adalah :

1. Penelitian ini mengkonfirmasi bahwa komitmen afektif menjadi hasil utama dari persepsi dukungan organisasi. Paradigma yang berlaku menyebutkan bahwa hasil dari persepsi dukungan organisasi adalah keterikatan emosional atau afeksi diri terhadap organisasi, dan kemudian kepuasan kerja. Begitu pula untuk lingkup PT Pos Indonesia Malang, para pegawai merasakan keterikatan emosional dan afeksi diri sebagai hasil dari penilaian mereka terhadap perlakuan yang diterima dari organisasi. Rasa berkewajiban sebagai wujud balasan perlakuan yang diterima pegawai dari organisasi ditemukan tidak dapat memberikan efek terhadap keterikatan emosional atau afeksi diri seorang pegawai PT Pos Indonesia Malang.

2. Penelitian ini mengkonfirmasi bahwa kepuasan kerja menjadi faktor utama dalam memberikan pengaruh terhadap perilaku kerja positif. Artinya sesuai dengan pendapat umum sebelumnya bahwa sikap terhadap pekerjaan atau dalam hal ini adalah kepuasan kerja sebagai faktor dominan dalam mempengaruhi perilaku dalam bekerja. Meski dalam hasil pengaruh baik kepuasan kerja, komitmen afektif, dan kewajiban yang dirasakan sama - sama memberikan efek terhadap perilaku dalam bekerja, ternyata kepuasan kerja yang mempunyai posisi lebih besar dibandingkan komitmen afektif atau kewajiban yang dirasakan pegawai. Sehingga individu lebih condong dalam pengharapan atas apa yang dipersepsikan dan yang melekat pada pekerjaannya, bukan perasaan keterikatan terhadap organisasi, atau bahkan perasaan berkewajiban dalam membantu organisasi mencapai tujuan. Hal ini yang berlaku pada pegawai di lingkup PT Pos Indonesia Malang.

3. Dari gambaran poin diatas juga memberikan informasi bahwa dalam kebanyakan kajian penelitian sebelumnya tentang persepsi dukungan organisasi atau dalam konteks pertukaran sosial, konstruk kepuasan kerja seringkali diukur dalam bentuk kepuasan kerja secara umum (global job satisfaction) yang langsung terdiri dari item - item tertentu saja dalam membentuk konstruk kepuasan tersebut. Melalui penelitian ini berdasarkan gambaran hasil penelitian memberikan khasanah baru bahwa dengan melandaskan pada teori persepsi nilai yang membentuk kepuasan kerja, memberikan hasil yang berbeda dalam efek persepsi dukungan organisasi dari pegawai. Walaupun masih terdapat catatan khusus bahwa tidak semua indikator yang membentuk kepuasan kerja ditemukan valid, hasil ini terutama mengacu kepada kepuasan terhadap atasan.

4. Penelitian ini memberikan masukan baru bahwa posisi komitmen afektif tidak selalu secara dominan posisinya dalam menengahi hubungan antara penilaian pegawai atas perlakuan yang diterima dari organisasi dengan perilaku pegawai dalam bekerja. Sekali lagi hal ini lebih disebabkan karena faktor penilaian pegawai terhadap apa yang melekat pada pekerjaan dan pengharapan mereka atas nilai - nilai yang diinginkan, lebih dominan dalam memprediksi perilaku dalam bekerja, dan lebih cenderung diposisikan sebagai hasil utama dari persepsi pegawai dalam menilai perlakuan yang diterima dari organisasi.

5. Penelitian ini mengkonfirmasi bahwa berdasarkan norma resiprokal atau timbal balik, pegawai lebih condong terhadap persepsi seorang pegawai dalam menyikapi nilai dan pengharapan yang melekat pada pekerjaan, tidak hanya dominan pada bentuk balasan perlakuan yang diterima dari organisasi berupa keterikatan emosional yang lebih tinggi dan ataupun perasaan berkewajiban untuk membantu organisasi mencapai tujuan yang diinginkan.

6. Penelitian ini mengkonfirmasi bahwa untuk dapat menampilkan perilaku bekerja yang positif sebagai efek atas dukungan yang diterima dari organisasi, seorang pegawai yang harus menyikapinya dalam bentuk 
perasaan yang mereka tunjukkan. Dengan kata lain bahwa efek dari persepsi dukungan organisasi terhadap perilaku kerja positif dapat bekerja apabila melalui sikap pegawai terhadap pekerjaannya (kepuasan kerja) dan organisasi (komitmen afektif dan kewajiban yang dirasakan).

\section{Implikasi Teoritis}

Beberapa hal yang berhubungan dengan implikasi teoritis dapat dijelaskan sebagai berikut :

1. Kepuasan kerja menengahi hubungan diantara persepsi dukungan organisasi terhadap perilaku kerja positif. Penelitian ini menggunakan indikator kepuasan terhadap gaji, kepuasan terhadap promosi, kepuasan terhadap rekan kerja, dan kepuasan terhadap pekerjaan itu sendiri yang dikembangkan dari. Hasil penelitian ini secara empiris memperkuat penelitian sebelumnya yang menyatakan bahwa persepsi dukungan organisasi mendorong kepuasan kerja. Sementara kepuasan kerja dapat meningkatkan perilaku kerja positif seorang pegawai.

2. Komitmen afektif menengahi hubungan diantara persepsi dukungan organisasi terhadap perilaku kerja positif. Hasil penelitian ini secara empiris memperkuat penelitian sebelumnya yang menyatakan bahwa persepsi dukungan organisasi mendorong komitmen afektif. Sementara komitmen afektif meningkatkan perilaku kerja positif seorang pegawai.

3. Kewajiban yang dirasakan menengahi hubungan diantara persepsi dukungan organisasi terhadap perilaku kerja positif. Hasil penelitian ini secara empiris memperkuat tentang penelitian sebelumnya yang menyatakan bahwa persepsi dukungan organisasi mendorong kewajiban yang dirasakan pegawai. Sementara kewajiban yang dirasakan meningkatkan perilaku kerja positif seorang pegawai.

Selain berkontribusi terhadap teori - teori yang terdahulu, penelitian ini juga memberikan implikasi terhadap kajian praktek perilaku organisasi di lingkup PT Pos Indonesia Malang antara lain bahwa :

Penelitian ini dapat mengkonfirmasi bahwa terdapat keseimbangan mutual yang cukup antara pertukaran nilai yang berlaku dalam lingkup organisasi PT Pos Indonesia Malang. Lebih spesifiknya adalah pegawai PT Pos Indonesia mempersepsikan dukungan organisasi yang dirasakan untuk kemudian membalas perlakuan yang diterima tersebut menjadi rupa bentuk yang beragam, termasuk dua jenis mekanisme sikap utama yang dibahas, yakni sikap pegawai terhadap pekerjaannya (kepuasan kerja) dan sikap pegawai terhadap organisasinya (komitmen afektif dan kewajiban yang dirasakan).

Penelitian ini dapat memberikan tambahan informasi bahwa sekalipun pegawai tidak dapat mempersepsikan atasannya dengan baik, hal ini tidak selalu menyiratkan bahwa banyak atasan dalam jajaran struktural yang bermasalah. Hanya yang perlu digarisbawahi adalah bagaimana pola hubungan antara atasan dan bawahan yang ada di lingkup PT Pos Indonesia Malang. Selain itu dengan tidak dimasukkannya kajian tentang persepsi dukungan dari atasan juga menjadi catatan khusus bahwa antara bentuk konstruk kepuasan terhadap atasan dengan persepsi dukungan dari atasan apakah merupakan bentuk yang berbeda atau tidak.

Penelitian ini dapat memberikan masukan bahwa untuk praktik kepegawaian di PT Pos Indonesia Malang, masih perlu pembenahan dalam struktur kepegawaian terutama untuk mengakomodir pegawai - pegawai yang mempunyai golongan kepangkatan tinggi tetapi tidak dalam posisi menjabat. Masih dirasa perlu merumuskan mekanisme kepegawaian yang lebih baik sehingga mampu mengakomodir pengembangan dan prestasi dari pegawai PT Pos Indonesia.

\section{Discussion}

The purpose of the present study was to examine the mediating roles of job satisfaction, affective commitment, and felt obligation of perceived organizational support toward positive work behavior. This study contributes to organizational literature on three counts. Its first contribution lies in adjustment that the results of this study could theoretically be depicted from proving causality between kostruk or latent variable perceptions of organizational support for the positive work behavior through job satisfaction, affective commitment, and perceived employee obligations PT Pos Indonesia Malang. In this case there are several findings in particular, include:

1. This study confirms that affective commitment to be the main result of the perception of organizational support. Prevailing paradigm states that the result of the perception of organizational support is an emotional or affective attachment to the organization itself, and then the job satisfaction. Similarly, for the scope of PT Pos Indonesia Malang, employees feel an emotional attachment and affection themselves as a result of its assessment of the treatment received from the organization. Sense of obligation as a form of retaliation treatment received employee of the organization was found to be able to give effect to the emotional attachment or affection herself an employee of PT Pos Indonesia Malang.

2. This study confirmed that job satisfaction is a major factor in influencing the behavior of the positive work. That is in accordance with previous public opinion that attitudes towards work or in this case job satisfaction as the dominant factor in influencing behavior at work. Despite the good results of the influence of job satisfaction, affective commitment, and perceived obligation same - the same effect on behavior at work, job satisfaction has 
turned out better position than affective commitment or perceived employee obligations. So that individuals are more inclined to the hope of what is perceived and attached to the job, not the feelings of attachment to the organization, or even a sense of duty in helping the organization achieve its goals. It is applicable to employees in the scope of PT Pos Indonesia Malang.

3. From the picture above points also informed that in most previous research study on perceptions of organizational support or in the context of social exchange, the construct of job satisfaction is often measured in terms of job satisfaction in general (global job satisfaction) were directly composed of items - certain items only in the form The satisfaction construct. Through this research based overview of the results of the study provide new repertoire grounded on the theory that the values that shape perceptions of job satisfaction, give different results in the effects of employee perceptions of organizational support. Although there is still a special note that not all of the indicators that make up the job satisfaction was found valid, the result is mainly refers to the satisfaction of the employer.

4. This research provides a new input that position affective commitment is not always a dominant position in mediating the relationship between employee assessment on the treatment received from the organization to the behavior of employees at work. Again, this is mainly due to valuation factors to what employees are attached to their work and hope for the value - the desired value, more dominant in predicting behavior in the work, and more likely to be positioned as the main result of the perception of employees in assessing the treatment received from organization.

5. This study confirmed that based on reciprocity norms or reciprocity, employees are more inclined towards the perception of an employee in addressing the values and expectations attached to the job, not only in the form of a reply dominant treatment received from the organization in the form of higher emotional attachment and or feeling obligated to help the organization reach its intended destination.

6. This study confirmed that in order to show the positive work behaviors as effects of the support received from the organization, an employee must respond in a sense that they show. In other words, the effect of perceived organizational support on positive work behaviors can work if through employee attitudes toward the job (job satisfaction) and organizational (affective commitment and perceived obligations).

Theoretical Implications Several issues related to the theoretical implications can be explained as follows:

1. Job satisfaction mediates the relationship between perceptions of organizational support for the positive work behaviors. This study used indicators of satisfaction with pay, satisfaction with promotion, satisfaction with coworkers, and satisfaction with the work itself developed from. The results of this study empirically reinforces previous research which states that perceived organizational support encourages job satisfaction. While job satisfaction can increase an employee of a positive work behaviors. 2. Affective commitment mediates the relationship between perceptions of organizational support for the positive work behaviors. The results of this study empirically reinforces previous research which states that perceived organizational support encourages affective commitment. While affective commitment enhance positive work behaviors an employee.

3. Perceived obligation mediates the relationship between perceptions of organizational support for the positive work behaviors. The results of this study empirically reinforce earlier research on the perception of support stating that the organization encourages employees perceived obligations. While the perceived liabilities increased positive work behaviors an employee.

In addition to contributing to the theory - the theory of the foregoing, this study also have implications for the study of organizational behavior in the scope of practice of PT Pos Indonesia Malang, among others that: This research can confirm that there is sufficient mutual balance between the exchange rate prevailing in the scope of the organization of PT Pos Indonesia Malang. More specifically an employee of PT Pos Indonesia perceives perceived organizational support and then reply to the treatment becomes a way diverse forms, including the two main types of mechanisms were discussed posture, the attitude of employees towards work (job satisfaction) and employee attitudes toward their organization (commitment affective and perceived obligations).

This research can provide additional information that employees can not even perceive his boss well, this does not necessarily imply that many employers in the ranks of structural problems. Only the bottom line is how the relationship between superiors and subordinates that is in the scope of PT Pos Indonesia Malang. In addition to the exclusion of the study of the perception of support from employers is also a special note that the form of the construct of satisfaction with the supervisor with the perception of support from superiors whether a different form or not.

This research can provide that input to employment practices in Malang PT Pos Indonesia, still needs improvement in the staffing structure primarily to accommodate employees - employees who have a high class rank but not in a position to shake. Still it is necessary to formulate a better staffing mechanism so as to accommodate the development and achievements of employees of PT Pos Indonesia. 


\section{Daftar Pustaka}

[1]. Allen, Natalie J., John P. Meyer. 1990. The Measurement and Antecedents of Affective, Continuance and Normative Commitment to the Organization. The British Psychological Society : Journal of Occupational Psychology Vol 63, No 1-18.

[2]. Allen, Natalie J., John P. Meyer. 1991. A ThreeComponent Conceptuali-zation of Organizational Commitment. Human Resource Management Review, Vol 1 No 1 pp 61 - 89.

[3]. Allen, Natalie J., John P. Meyer. 1991. Affective, continuance, and normative commitment to the organization. Journal of Vocational Behavior 49: 252-276.

[4]. Allen, David G., Lynn M. Shore, Rodger W. Griffeth. 2003. The Role of Perceived Organizational Support and Supportive Human Resource Practices in the Turnover Process. Elsevier Science Inc. : Journal of Management 2003 29(1) 99-118.

[5]. Armeli, Stephen, Robert Eisenberger, Peter Fasolo, dan Patrick Lynch. 1998. Perceived Organizational Support and Police Performance: The Moderating Influence of Socioemotional Needs. American Psychological Association, Inc. : Journal of Applied Psychology 1998, Vol. 83, No. 2, 288-297.

[6]. Arshadi, Nasrin. 2011. The relationships of perceived organizational support (POS) with organizational commitment, in-role performance, and turnover intention: Mediating role of felt obligation. Procedia - Social and Behavioral Sciences 30 (2011) 1103 1108

[7]. Aselage, Justin, Robert Eisenberger. 2003. Perceived Organizational Support and Psychological Contracts: A Theoretical Integration. Journal of Organizational Behavior : No 24, 491-509.

[8]. Brandt, R. B. 1964. The Concepts of Obligation and Duty. Oxford University Press - Mind Association : Mind, New Series, Vol. 73, No. 291 (Jul., 1964), pp. 374-393.

[9]. Colquitt, Jason A, Jeffery A Lepine, Michael J Wesson. 2009. Organizational Behavior : Improving Performance and Commitment in The Workplace. McGraw - Hill / Irwin.

[10]. Eisenberger, R., Huntington, R., Hutchison, S., Sowa, D. 1986. Perceived Organizational Support. American Psychological Association, Inc. : Journal of Applied Psychology, Vol 71, No 3, 500-507.

[11]. Eisenberger, Robert, Peter Fasolo, dan Valerie Davis-LaMastro. 1990. Perceived Organizational Support and Employee Diligence, Commitment, and Innovation. Journal of Applied Psychology Vol. 75, No. 1, 51-59.

[12]. Eisenberger, Robert ; Jim Cummings, Stephen Armeli, and Patrick Lynch. 1997. Perceived Organizational Support, Discretionary Treatment, and Job Satisfaction. American Psychological Association, Inc. : Journal of Applied Psychology, 1997, Vol. 82, No. 5, $812-820$.

[13]. Eisenberger, Robert, Stephen Armeli, Barbara Rexwinkel, Patrick D. Lynch, Linda Rhoades. 2001. Reciprocation of Perceived Organizational Support. Journal of Applied Psychology. Vol 86, No 1, $42-51$.

[14]. Ghozali, Imam. 2008. Model Persamaan Struktural Konsep dan Aplikasi. Semarang : Badan Penerbit UNDIP.

[15]. Greenberg, Jerald, Robert A Baron. 2008. Behavior in Organizatation 9e. Prentice Hall Pearson International Edition.

[16]. Griffin, Mark A., Andrew Neal, Sharon K. Parker. 2007. A New Model Of Work Role Performance : Positive Behavior In Uncertain And Interdependent Contexts. Academy of Management Journal : 2007, Vol. 50, No. 2, 327-347.

[17]. Guest, David E. 2004. The Psychology of the Employment Relationship: An Analysis Based on the Psychological Contract. Blackwell Publishing - Applied Psychology : An International Review, 53 (4), 541-555.

[18]. Hair, J.F., Black, W.C., Babin, B.J., Anderson, R.E. 2010. Multivariate Data Analysis. $7^{\text {th }}$ Edition. New Jersey : Pearson Education Inc.

[19]. Hulin, C. L., dan Judge, T. A. 2003. Job attitudes: A theoretical and empirical review. Dalam W. C. Borman, D. R. Ilgen, \& R. J. Klimoski (Eds.), Handbook of psychology (Vol. 12, pp. 255-276). Hoboken, NJ: Wiley.

[20]. Hunter, Karen Heather. 2011. Organizational Support and Motivation Theories: Theoretical Integration and Empirical Analysis. University of Alberta : Dissertation.

[21]. Jawahar I.M., Pegah Hemmasi. 2006. Perceived organizational support for women's advancement and turnover intentions The mediating role of job and employer satisfaction. Emerald Group Publishing Limited : Women in Management Review Vol. 21 No. 8 , pp. 643-661.

[22]. Jex, Steve M. 2002. Organizational Psychology : A Scientist-Practitioner Approach. New York : John Wiley \& Sons.

[23]. Judge, Timothy A., dan Klinger, R. 2007. Job satisfaction: Subjective well-being at work. In M. Eid \& R. Larsen (Eds.), The science of subjective well-being (pp. 393-413). New York: Guilford Publications.

[24]. Judge, Timothy A., dan Klinger, R. 2009. Promote job satisfaction through mental challenge. In E. A. Locke (Ed.), Handbook of principles of organizational behavior. Chichester, UK: John Wiley \& Sons.

[25]. Lew, Tek -Yew . 2009. The Relationships between Perceived Organizational Support, Felt Obligation, Affective Organizational Commitment and Turnover Intention of Academics working with Private Higher Educational Institutions in Malaysia. European Journal of Social Sciences - Volume 9, Number 1.

[26]. Liu, Wei. 2004. Perceived Organizational Support : Linking Human Resource Management Practices With Important Work Outcomes. Dissertation submitted to the Faculty of the Graduate School of the University of Maryland, College Park.

[27]. Lynch, Patrick D., Robert Eisenberger, Stephen Armeli.1999. Perceived Organizational Support : Inferior Versus Superior Performance by Wary Employees. American Psychological Association : Journal Of Applied Psychology Vol. 84, No. 4, 467 - 483.

[28]. Nijhof, Wim J; Margariet J. de Jong \& Gijs Beukhof .1998. Employee Commitment in Changing Organisations : an Exploration. MCB University Press : Journal of European Industrial Training Vol. 22/6, pp. 243-248.

[29]. Pack, Simon. 2005. Antecedents and Consequences Of Perceived Organizational Support For NCAA Athletic Administrators. Dissertation Graduate School of The Ohio State University.

[30]. Pazy, Asya dan Yoav Ganzach. 2009. Pay Contingency and the Effects of Perceived Organizational and Supervisor Support on Performance and Commitment. Journal of Management, Vol. 35 No. 4, August 2009 1007-1025.

[31]. Poloma, Margaret M. 2010. Sosiologi Kontemporer. Jakarta : Rajawali Press.

[32]. Randall, Marjorie L., Russell Cropanzano, Carol A. Bormann, Andrej Birjulin. 1999. Organizational politics and organizational support as predictors of work attitudes, job performance, and organizational citizenship behavior. John Wiley \& Sons, Ltd. : Journal of Organizational Behavior Vol 20, 159 \pm 174 (1999).

[33]. Rhoades, Linda dan Robert Eisenberger. 2002. Perceived Organizational Support : A Review of the Literature. American Psychological Association, Inc. : Journal of Applied Psychology Vol 87, No. 4, 698 - 714.

[34]. Rhoades, Linda, Robert Eisenberger dan Stephen Armeli. 2001. Affective Commitment to the Organization : The Contribution of Perceived Organizational Support. American Psychological Association : Journal of Applied Psychology Vol. 86, No. 5, 825 - 836.

[35]. Robbins, Stephen. 2007. Organizational Behaviour 12e. Prentice Hall.

[36]. Robinson, Sandra L, Matthew S. Kraatz, Denise M. Rousseau. 1994. Changing Obligations and The Psychological Contract : A Longitudinal Study. Academy of Management Journal Vol. 37, No 1., 137 - 152. 
[37]. Shore, Lynn M dan Harry J. Martin. 1989. Job Satisfaction and Organizational Commitment in Relation to Work Performance and Turnover Intentions. Human Relations Volume 42 Number 7, 1989, pp. 625 - 638

[38]. Shore, Lynn M dan Lois E. Tetrick. 1991. A Construct Validity Study of the Survey of Perceived Organizational Support. American Psychological Association, Inc. Journal of Applied Psychology 1991, Vol. 76, No. 5,637-643.

[39]. Shore, Lynn M dan Sandy J. Wayne. 1993. Commitment and Employee Behavior: Comparison of Affective Commitment and Continuance Commitment With Perceived Organizational Support. American Psychological Association, Inc. Journal of Applied Psychology 1993, Vol. 78, No. 5, 774-780.

[40]. Suliman, Abubakr dan Paul Iles. 2000, Is continuance commitment beneficial to organizations? Commitment-performance relationship: a new look. MCB University Press : Journal of Managerial Psychology, Vol. 15 No. 5, pp. 407-426.

[41]. Suliman, Abubakr M., Paul A. Iles. 2000. The multi-dimensional nature of organisational commitment in a non-western context. MCB University Press : Journal of Management Development, Vol. 19 No. 1, 2000, pp. $71-82$.

[42]. Suliman, Abubakr M.T. 2002, Is it really mediating construct? The Mediating Role of Organizational Commitment in Work Climate - Performance Relationship. MCB University Press Limited : Journal of Management Development, Vol.21 No.3, pp. 170-183.

[43]. Tett, Robert P., Kevin E. Fox dan Penelope C. Palmer. 2003. Task and Contextual Performance as Formal and Expected Work Behaviors. 18th Annual Conference of the Society for I and O Psychology, April 2003.

[44]. Wayne; Sandy J, Lynn M Shore;,Robert C Liden. 1997. Perceived Organizational Support and Leader-Member Exchange : A Social Exchange Perspective. Academy of Management Journal; Vol 40 No 1, $82-11$. 